\title{
The Waterlogged Limits of the Infrastructural State: The Failure of the T'aean Canalization Projects in Pre-Industrial Korea, 1134-1537*
}

John S. Lee**

One of the chronic problems of pre-industrial Korean history has been that of infrastructural integration. Throughout the Koryŏ (918-1392) and Chosŏn dynasties (1392-1910), the Korean peninsula's mountainous landscape and uncooperative waters hampered large-scale flows of bulk resources between the agricultural southernmost provinces and the heavily populated Han and Taedong river basins. Of course, governments on the Korean peninsula were not blind to the problem. Both maritime and terrestrial infrastructures were priorities of the Koryŏ and Chosŏn dynasties. This article focuses on a particular series of infrastructural projects: from 1134 to 1537, Koryŏ and Chosŏn governments made five major attempts to build a viable canal through the

* This research was supported by the Korean Studies Grant Program of the Academy of Korean Studies (AKS-2019-R54). Aspects of this article were first presented in 2011 at the biennial meeting of the Association for Korean Studies - Europe. Special thanks to Ling Zhang and Sixiang Wang for their comments on early drafts; Eugene Y. Park for arranging a field trip to the T'aean area in 2013; the participants of the Environmental History Workshop at Northumbria University in 2019 for their feedback and suggestions; and the three anonymous reviewers for their kind comments and crucial corrections.

** Department of History, Durham University, Assistant Professor in East Asian History 
T'aean peninsula on Korea's Yellow Sea coast.

Located along a critical shipping route for southern grain headed to the capital region, the T'aean peninsula had been infamous since the Koryŏ era for its rough waters, unpredictable tides, and proclivity for hastening shipwrecks. A successful canal would have allowed grain ships to bypass the treacherous tidal flats at the western base of the T'aean peninsula, an area known as the Anhŭng headland. However, due to government inabilities to mitigate the area's formidable environmental obstacles namely, its extreme tidal fluctuations and hard granite bedrock - no viable canal was ever finished.

Moreover, I argue that the canal projects' repeated failures exposed early Chosǒn centralization's logistical and technological limits - limits that, in turn, would shape the political economy of the Chosŏn state. A comparison with late imperial Chinese hydraulic projects is quite apt here. For Chinese states, the maintenance of the Grand Canal and other waterways was critical to the political and economic well-being of both the state and the localities. Accordingly over time, Chinese officials built up an impressive array of hydraulic institutions and knowledge partly in order to ensure the regular flow of goods and people between China's cores and peripheries. ${ }^{1}$ In contrast, over the course of the Chosŏn dynasty, the state would take on a more hands-off approach to transport shipping. From the mid-seventeenth century onward, the Chosŏn state would invest in granaries and riverine transport rather than more ambitious maritime infrastructure such as the T'aean canalization efforts.

The repeated attempts and failures of the T'aean canals highlight three convergences of environmental and institutional factors: environmental limits; institutional inertia; and the particularities of socio-environmental relationships. The granite bedrock and sandy soil that underpins the $\mathrm{T}$ 'aean region strained the technological and bureaucratic capacities of the

1 Joseph Needham, Wang Ling, and Lu Gwei-djen, Science and Civilisation in China, vol. 4, Physics and Physical Technology, Part III: Civil Engineering and Nautics (Cambridge: Cambridge University Press, 1971), 211-378. 


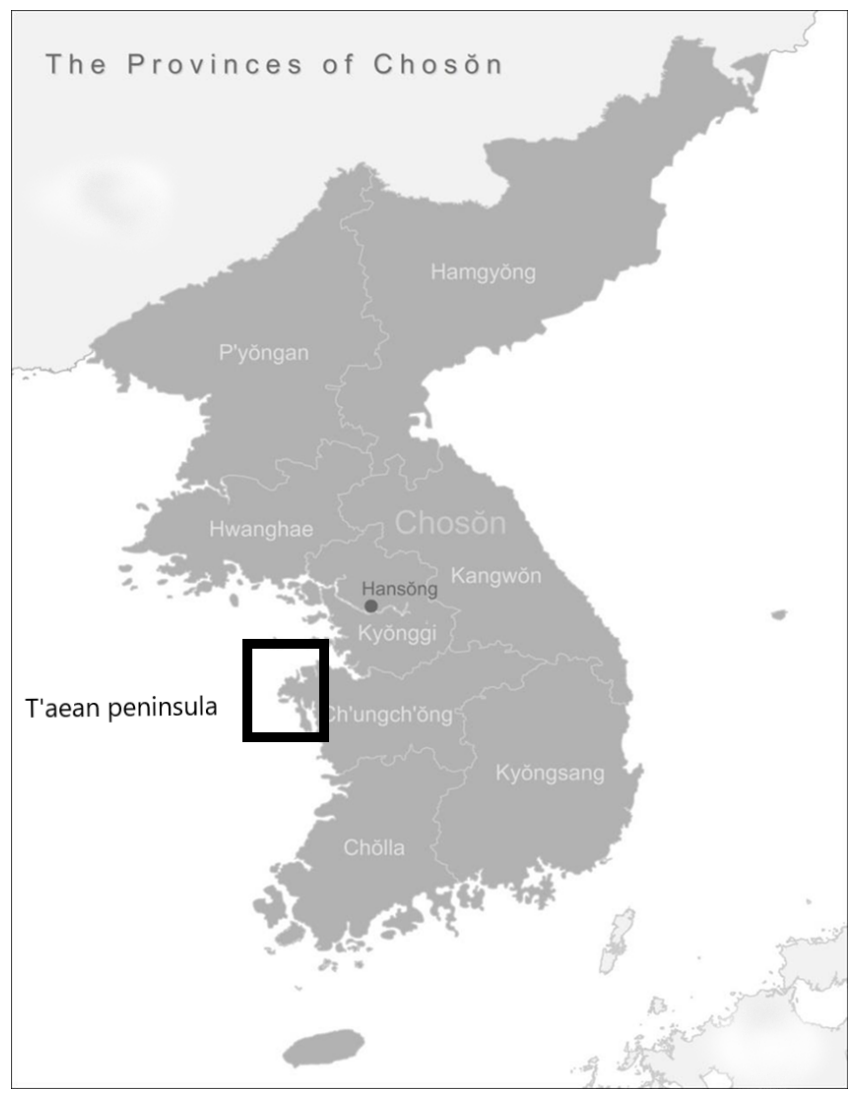

Fig.1. Location of the T'aean region

Koryŏ and Chosŏn eras. Yet, successive governments pressed on with canalization projects in the same area for centuries. Environmental systems, in particular, can be prone to "institutional inertia," the tendency for institutions to continue along pre-existing paths. ${ }^{2}$ Cost, geography,

2 R. Beunen and J.J. Patterson, "Analysing institutional change in environmental governance: exploring the concept of "institutional work," Journal of Environmental Planning and Management 62, no.1 (November 2019), 12-29; Johan Munck af Rosenschöld, Japp G. Rozema, and Laura Alex Frye-Levine, 
and uncertainty factored into government decisions to maintain the same pattern of infrastructural decisions. Finally, the canalization projects grew out of particular relationships between state, society, and the environment. For canalization labor, the Chosŏn state utilized populations such as soldiers, corvée laborers, and Buddhist monks who were deemed expendable for infrastructural projects. However, the same populations lacked any social or economic relationship with the canals and their environs. Many workers absconded, and the government's ability to extract the necessary labor diminished over time.

Overall, the Korean governments' inability to finish the T'aean canals was indicative of the environmental limits of infrastructural expansion in pre-industrial Korea. Over time, the Chosŏn state would rely more and more on private brokers to ship southern grain, and administrative expansion would largely unfold through the incorporation of local elites and administrative agents in the latter half of the dynasty. ${ }^{3}$ All the while, ships and sailors would continue to meet their demise in the Anhŭng mud flats, but that would be a price the Chosonn state was willing to pay.

\section{The Five Canalization Attempts, 1134-1537}

The Anhŭng headland and the wider T'aean peninsula is part of the Korean western and southern coastal landform famous for its considerable tide variation. The region is defined by endless submerged mud flats and treacherous currents that bedeviled ships of the Koryŏ and Chosǒn periods. A single miscalculation could wreck the ships in the thick mud flats, or worse, in the rocky outgrowths and reefs that dot the shallow waters. The original name for the westernmost headland was "Nanhaeng"

"Institutional inertia and climate change: a review of the new institutionalist literature," Wiley Interdisciplinary Reviews 5 (May 2014): 639-648.

3 John S. Lee, "The Rise of the Brokered State: Situating Administrative Expansion in Chosŏn Korea," Seoul Journal of Korean Studies 32, no.1 (June 2019): 81-108. 
難行, “the difficult passage."; Superstitious sailors, wary of such a foreboding name, called the area “Anhŭng” 安興 or “peaceful headland” in hopes that the new nomenclature would pacify the strait. ${ }^{4}$

The first governmental initiatives to overcome Anhŭng's obstacles came in 1134 during the reign of Koryŏ's King Injong (r. 1122-1146). An 1134 entry in the Standard Koryŏ History (Koryǒsa) cites an unnamed official who advocates building a "waterway" (hado) to expedite shipping through "Sodae," a Koryŏ-era name for the T'aean peninsula. The Koryŏsa entry notes that waters around the Anhŭng headland were filled with "rapid currents" and "dangerous rocks." Accordingly, a court eunuch named Chŏng Sŭmmyŏng (?-1151) was sent to the area to oversee a major canalization project. "Thousands of soldiers" were sent to work on the canal; however, it was never finished. ${ }^{5}$ The work was taken up again in 1154 by Injong's successor, King Üijong (r. 1146-1170); he too failed to complete the canal. ${ }^{6}$

Later reports indicate that the first canal, known in records as the "Kulp'o" project after an old name for T'aean, was planned for a length of eight kilometers, and the Koryŏ kings completed approximately 4.5 kilometers before quitting. ${ }^{7}$ Two reasons explain the project's termination. First, the base of the T'aean peninsula is layered in thick granite that challenged the mid-Koryŏ technological repertoire. Secondly, the builders lacked any efficient means for discharging incoming tides and the accompanying mud flats. The region's high ebbing tides, long so cursed by local sailors, would trouble not only the twelfth-century project

4 Kang Hang (1567-1618), a Korean war captive taken to Japan during the Imjin War, gave a brief account of the strait's nomenclature to his captors and accordingly recorded his description in his diary. Jahyun Kim Haboush and Kenneth Robinson, eds., A Korean War Captive in Japan, 1597-1600: The Writings of Kang Hang (New York, NY: Columbia University Press, 2013), 4.

5 Koryŏsa [Standard Koryŏ History] 17.30b.

6 Koryŏsa chŏryo [Essentials of Koryŏ History] 11.16a.

7 Koryŏsa 116.19a-19b. 
but all subsequent canal construction in the T'aean region.

Mongol invasions in the thirteenth century and pirate raids from the Japanese archipelago in the fourteenth century prevented any further canalization work in the T'aean peninsula region for almost two hundred years. Finally, in 1391, a civil official named Wang Kang (?-1394), who was a distant relative of the Koryŏ royal family, proposed rebuilding the Kulp'o canal from a north-to-south direction. His plan was ingenious; Wang suggested digging from north to south in order to link up with the remnants of the twelfth-century Kulp'o project:

Between the north and south ends, there is a channel built long ago. The section that has been deeply excavated is over $10 \mathrm{li}$ [approx. 4.5 kilometers], and [the section] that has yet to be excavated is not more than $7 \mathrm{li}$ [approx. 3 kilometers]. If we complete the excavation and link the ocean waters, then every year, transport ships can avoid the dangerous $400 l i$ of the Anhŭng headland. I propose to start construction in the seventh lunar month and finish in the eighth month. ${ }^{8}$

The ambitious one-month timetable implies that previous canalization works were still in serviceable condition, and Wang must have been confident that he could rapidly build upon the existing infrastructure. Unfortunately, Wang Kang's project met the same fate as his predecessors'. According to the Koryŏsa, "due to the rocks under the waters and the coming and going of the tides, anything excavated immediately filled up. ${ }^{.9}$ Yet again, the combination of reefs, tides, and an uncompromising granite bedrock stymied a governmental attempt to circumvent the Anhŭng headland.

The next year, in 1392, the general Yi Sŏnggye (King T'aejo, 13351408) declared a new dynasty, the Chosŏn. In line with the wave of new

8 Koryŏsa 116.19a-19b.

9 Koryŏsa 116.19a-19b. 
state formation across post-Mongol Eurasia, the new Chosǒn government embarked on an ambitious policy of centralization. It moved the capital to Hanyang (present-day Seoul), established new administrative subdivisions, bestowed provincial governors with higher status and farranging powers, and revamped the land system in favor of greater access for members of the central bureaucracy. Officials also improved the granary system to further ensure the shipment of grain as taxes to Seoul and as famine relief to suffering areas.

The new and improved granary system was critical to early Chosǒn centralization. Grain from Chŏlla province in particular brought in precious revenue necessary to pay the growing civil and military bureaucracies; furthermore, the grain could be distributed to various localities to assuage famine and ensure loyalty to the new regime. New granaries were strategically placed along the southern coast to ease the shipment of rice to the sea, whereupon the grain could be shipped to any part of the peninsula. ${ }^{10}$ The government also tightly regulated everything from vessel sizes and delivery times to the number of boatmen per ship, thus demonstrating the high priority placed on the granary system and extent to which the early Chosonn government directly controlled the shipment process. ${ }^{11}$

However, early Chosŏn centralization efforts also expanded the amount of maritime traffic through treacherous areas such as the Anhŭng headland. The number of shipwrecks skyrocketed during the early Chosǒn period. The Annals of the Chosŏn Dynasty (Chosŏn wangjo sillok) notes sixteen ships met untimely fates in $1395,{ }^{12}$ ninety-eight would be

10 Kanno, Shuichi “Chosŏn ch'ogi chinhyulgok unsong munje: Chosŏn wangjo ǔi kukka chŏk chaebunbae kinŭng e taean koch'al [The problem of famine-relief grain transportation in the early Chosǒn era: An examination of the state redistributive functions of the early Chosǒn dynasty]," Komunsǒyŏn'gu 22 (February 2003): 193222

11 Choe Wan'gi, Chosŏn hugi sŏnunŏpsa yŏn'gu [A history of transport shipping in the late Chosŏn era] (Seoul: Ilchogak, 1993), 8-15 
wrecked in 1403, ${ }^{13}$ and sixty-six shipwrecks are recorded for $1414 .{ }^{14}$

Facing a loss of tax revenue and the disruption of the famine-relief system, the early Chosǒn government took action. King T'aejong (13671422, r. 1400-1418) dispatched officials to investigate the remnants of the Koryŏ-era Kulp'o canal. In 1412, Chief State Councilor Ha Ryun (13471416) submitted the following proposal:

The place where Wang Kang attempted excavation has elevated geological features, and so if embankments are laid in accordance with lowering [elevations], then the water is trapped [therein]. If we placed small boats along each embankment, and [the space] between the embankments is excavated, then when a transport ship enters port, we can move [the goods] to the small boats. After the small boat passes between the embankments, we can load the goods on to [another set] of small boats between the embankments. ${ }^{15}$

Thus, Ha Ryun attempted to circumvent past failures. Rather than wasting time and labor trying to build a canal for regular transport ships in such an environmentally treacherous zone, Ha suggested constructing a smaller waterway of five connected reservoirs manned by sets of small boats. Larger transport ships could berth near the entrance reservoirs and then move their goods onto smaller vessels for travel through the new canal. Though some officials warned that the granite rock bed would be

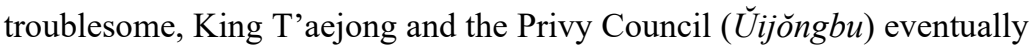
approved the plan.

Ha Ryun's canal built upon existing infrastructure, and the project was

12 Chosón wangjo sillok [The annals of the Chosŏn dynasty], T'aejo Sillok 4.8.7. All entries from Chosŏn court records are cited in reign year-month-day format.

13 T'aejong sillok 3.5.5.

14 T'aejong sillok 14.8.4.

15 T'aejong sillok 12.11.16. 
reported finished within several months in 1412 and 1413. The canal had the following dimensions, listed by each of the five reservoirs and their

\begin{tabular}{|l|c|c|c|}
\hline \multicolumn{1}{|c|}{ Section } & $\begin{array}{c}\text { Length } \\
\text { (meters) }\end{array}$ & $\begin{array}{c}\text { Width } \\
\text { (meters) }\end{array}$ & $\begin{array}{c}\text { Depth } \\
\text { (meters) }\end{array}$ \\
\hline Southern Reservoir & 81.22 & 39.10 & 1.80 \\
\hline Southern Sectional Embankment & 30.08 & 12.03 & 5.41 \\
\hline Southern Embankment & 141.14 & 12.03 & 5.41 \\
\hline Northern Embankment & 60.16 & 12.03 & 5.41 \\
\hline Northern Reservoir & 32.03 & 18.65 & 1.5 \\
\hline
\end{tabular}

Fig. 2. Sections and dimensions of Ha Ryun's canal

names. ${ }^{16}$

However, problems soon ensued. The granite bedrock still prevented deep excavation, thus explaining the rather shallow proportions of $\mathrm{Ha}$ Ryun's canal. Even after the initial construction was finished, the inevitable tides continued to spill through, and workers had to maintain an arduous process of dredging mud and removing water. Moreover, the environment remained uncooperative. Official reports noted that reefs, rocks, and strong winds prevented larger ships from berthing near the canal entrances. ${ }^{17}$

Meanwhile, ministers back in the court grumbled at the high costs of a project they felt would never succeed. "In vain, [Ha Ryun] wastes the people's labor" the opposing ministers declared, "even though inevitably there will be no profitable use. In the end, transports ships will not be able to transit." 18 Sensing the partisan opposition in court, Ha Ryun warned the king in the eighth month of 1413 that "the digging and transportation works must not be abandoned." The king responded saying, "Everyone says that the project is not feasible." Upon Ha Ryun's urging however, the king agreed to send civil officials Pak Chach'ŏng (1357-1423) and Kim Hyoson (1373-1429) to T'aean to investigate the canal works. Pak

16 T'aejong sillok 13.2.10.

17 T'aejong sillok 13.3.12.

18 T'aejong sillok 13.2.10. 
reported back saying, "If the various ministers went between the eighth and fifteenth days of the month and saw the ebb and flow of the tides, then they would understand." The king agreed with Pak's assessment. ${ }^{19}$

What was Pak's meaning? The eighth day of the lunar month is typically a first quarter moon that yields a low neap tide; the fifteenth day, on the other hand, results in a full moon and high tide. Thus, in that time span, one could witness the extreme fluctuations of the infamous Korean west coast tides - and the extreme troubles that the tides were wreaking on Ha Ryun's canal project. The king's agreement with Pak signaled the demise of Ha's innovative but ultimately futile canalization scheme. The next year, in 1414, the court ministers agreed to decrease the rice shipment quotas for the southern provinces, thus surrendering precious revenue in order to reduce the number of shipwrecks in the Anhŭng region. ${ }^{20}$

A fourth canalization attempt came in less than fifty years, in 1456, during the reign of King Sejo (r.1455-1468). In the second month of that year, the Chosŏn government issued a series of edicts that included the following:

The old dug-out harbors in T'aean are to be once again be excavated. Whether transport ships can transit and whether there are areas that [can be] excavated are to be thoroughly investigated. ${ }^{21}$

There are two likely reasons for the government's resurrection of the canal projects. First of all, 1455 was a terrible year for shipwrecks, with over fifty-four reported in the Sillok. Second, Sejo had a notable desire to

19 T'aejong sillok 13.8.1.

20 Kim Hyŏnjun "Anhŭngnyang ŭi kulp'o: miwansŏng ŭi unha kongsa [The excavation of the Anhŭng headland: canal construction in Miwansŏng]," Chayŏn kwa munmyŏng ǔi chohwa 4, no.8 (August 2001): 9.

21 Sejo sillok 2.7.15. 
raise central authority; his reign would see the execution of numerous dissenting ministers, the promulgation of the Great Code of Administration (Kyŏngguk Taejŏn), and territorial expansion against the Jurchens in the northern frontier. In 1461, Sejo sent the famed minister Sin Sukchu (1417-1475) to T'aean to investigate the feasibility of excavation along Wang Kang and Ha Ryun's previous channel. ${ }^{22}$ Three years later, Sin Sukchu led another group of officials and even two princes to visit and survey the old Kulp'o works. ${ }^{23}$

After 1464 however, there were no further canalization efforts during Sejo's reign. Sin Sukchu lamented the aborted project in a poem:

On top of the ridge is a lonely fort at the edge of the setting sun.

I climb to view to only see

the sea floating on sky.

The wind blows around the island

misty in fierce waves.

From remote homes,

thin smoke arises.

The port excavation was some years ago,

success not being reached.

From the mountain came a cord,

cut and retied.

Can someone explain to me

a plan for linking transport?

Drunk in front of my goblet, I idly try to forget. ${ }^{24}$

22 Sejo sillok 7.7.19.

23 Sejo sillok 10.3.9.

24 Sin Sukchu “Ch'a t'aean tonghŏn'un," Pohanchae chip 9 [1487], reprinted in Han'guk yŏktae munjip DB, vol. 59 (P'aju, South Korea: Han'guk yŏktae munjip DB), 347. Cited in Kwak Hoje, 'Koryŏ-Chosŏn sidae t'aean pando choun ǔi silt'ae 
One can conjecture that the age-old problems - the hard granite, the fierce tides - had again stymied King Sejo's canalization plans. Sin's poem reflects the frustration wrought by the T'aean peninsula's uncooperative waters. For centuries, Korean kings and ministers had pushed so much effort into circumventing the Anhŭng headland. Unfortunately, like the alluring cord dangling in Sin's poem, a successful canal would be but an unfortunate dream, to be cut by tides and granite, retied by ambitious kings and ministers, and cut again by nature's wrath.

During the reign of King Chungjong (r. 1506-1544), Chosǒn statesmen made one last attempt to circumvent the area's cursed waters. In 1521, civil official Ko Hyŏngsan (1453-1528) proposed a new canalization project to the west of the older works, near the village of Uihang, in an area far closer to the Anhŭng headland:

If we excavate the Anhŭng headland and Ǔihang [area] in order to integrate transport shipping, then it would be possible to be free from the curse of shipwrecks and lay profit for ten thousand generations. I wish to employ sailors and marines to excavate it. ${ }^{25}$

Ko Hyŏngsan's plan had two major advantages. First, unlike most of the T'aean peninsula, the Üihang area had a sandy bed; there would be no bedeviling granite. Secondly, the proposed canal length was much shorter, with a total length of just over two kilometers. Thus, the plan certainly seemed feasible, and the king approved Ko's plan. Ko mobilized over three thousand troops and worked on the project for over four months. However, just as they were on the verge of completion, the project was abandoned in 1522. Korean historian Yi Chongyŏng has argued that

wa unha kulchak [Canal excavation and the context of transport in the T'aean peninsula during the Koryŏ and Chosŏn eras]," Chibangsa wa chibang munhwa 12, no.1 (May 2009): 316.

25 Chungjong sillok 17.1.8. 
intense factional court politics throughout the sixteenth century often sapped centralization projects of their funding and support; similar circumstances affected the first Üihang canalization efforts. ${ }^{26}$

Environmental and labor issues further hampered the Uihang project. While the new location avoided the granite bedrock, the sandy soil necessitated constant dredging of the canal in order to prevent siltation. Dredging, in turn, required a steady supply of corvée labor - an institution that, by the sixteenth century, commoners were steadily trying to avoid through payment and flight.

In 1535, Chief State Councilor Kim Kŭnsa (1466-1539) offered a solution to the labor problem: the conscription of Buddhist monks for canalization and dredging work. In parts of Korea, including the area around T'aean, Buddhist monasteries were destinations for commoners trying to avoid corvée and military obligations. Although the early Chosŏn era is conventionally seen as an age of anti-Buddhist persecution, monks still enjoyed meager protections unattainable for the average commoner. ${ }^{27} \mathrm{Kim} \mathrm{Kŭnsa}$, in a diatribe against the rising number of people fleeing to monasteries, proposed conscripting monks between 20 and 60 years of age and using them to rebuild the Üihang canal:

The excavation of the Anhŭng headland has always been a constant concern of the state. Multiple times, it was on the brink of success and then stopped halfway, to the consternation of its supporters. If we drive out these [monks'] idle hands and make use of their labor, then they will be of profit to the state. ${ }^{28}$

26 Yi Chongyŏng, Chosŏn chŏn'gi sahoe kyŏngjesa yon'gu [A study of the social and economic history of the early Chosǒn era] (Seoul: Yonsei kukhak ch'ongsŏ, 2003), 184.

27 Kim Sŭngnam, "16 segi Chosŏn ŭi p'iyŏk sŭng ŭi chŭngga wa sŭngdo chojik ŭi chaegŏn [The rise in labor-avoidant monks and monastic reorganization in sixteenth-century Chosŏn]," Chosŏn sidaesa hakpo 66 (September 2013): 53-88.

28 Chungjong sillok 30.8.11. 
King Chungjong approved Kim Kŭnsa's plan, and he ordered "skilled" monks to be transferred to the Anhŭng headland to, yet again, resurrect a canal. ${ }^{29}$ A lower-level official named Yi Hyŏn (?-?) was appointed as "Director of Anhŭng Headland and Kul'po" (Anhŭng Kulp'o kyongch'agwan) to oversee the initial excavation process.

The next year, in 1536, Yi Hyŏn proposed a canalization plan to the court. He noted that the Kulp'o location from earlier eras was unsuitable due to the channel only reaching the depths of "two men," thus rendering it unsuitable for larger ships. Chosŏn officials still faced the same problem of the uncompromising granite bedrock. Instead, Yi advocated for another attempt at the Üihang route at the western tip of the T'aean peninsula. In order to overcome the sandy soil, he proposed an ingenious solution:

The [Üihang] location is laden with sand. If we dig up [the sand], lug it on our backs, and throw it out over our shoulders, then the labor costs would be too great. However, if we load the sand on ships and throw it in the ocean, the work would be quite easy. ${ }^{30}$

At a subsequent meeting of the High State Councilors, court ministers agreed that Yi Hyŏn's plan and the terrain around Uihang seemed promising, and they reiterated the benefits of expediting grain shipments from Chŏlla and Kyŏngsang provinces. However, officials also noted the long legacy of canalization failures in the same region. Accordingly, officials took a cautious approach. Authority over the project was given to the Board of Taxation (Hojo), and the government dispatched a series of officials to carefully survey the terrain and related labor and resource requisitions. ${ }^{31}$

29 Chungjong sillok 30.8.11.

30 Chungjong sillok 31.9.1. 
Increased bureaucratic oversight also ensured that Yi Hyŏn would lose his directorship. The Board of Taxation (Hojo) and King Chungjong wanted a new director of higher rank who could "deal with written documents," implying that Yi Hyŏn, while clearly a clever planner, was not of considerable education or status. Only two months after submitting his new canalization plan, Yi Hyŏn was demoted to assistant director under Pak Suryang (1491-1554), a civil examination passer with the right lineage and credentials. ${ }^{32}$ While Yi maintained oversight powers under a succession of new head directors, his demotion also augured a level of official distrust toward a social upstart.

By the spring of 1537, the government had gathered over 5,000 laborers, mostly monks, from several different provinces at the Üihang canalization site. ${ }^{33}$ By the middle of 1537 , they had completed the canal, and King Chungjong issued a promulgation praising Yi Hyŏn and his latest head director, a military official named Kim Kongsŏk (1477-1553). Celebrating their accomplishment of a task that "his own royal ancestors could not achieve," Chungjong issued promotions and rewards to both men, including a horse of highest stock for each. Yi Hyŏn was promoted into the upper ranks of officialdom (Tangsagwan), a notable feat for a man lacking an evident civil or military examination degree. ${ }^{34}$

Unfortunately, the canal soon collapsed due to familiar issues: the environment and labor. In a matter of months, the canal once again silted up, and monks tasked with dredging had fled. Though Yi Hyŏn may have had an excellent plan for sand removal, he did not implement a viable solution for controlling the tides. Without strong barriers against the area's tidal fluctuations and a reliable labor force to support them, any embankments would have gradually weakened to the point that sand and

31 Chungjong sillok 31.9.27.

32 Chungjong sillok 31.11.26.

33 Chungjong sillok 32.4.6.

34 Chungjong sillok 32.7.17. A royal gift of a horse (sungma) was considered one of the most prestigious honors in Chosŏn. 
mud filled the channel. In 1538, Hwang Hŏn (1502-1574), a high-ranking official from the Office of the Inspector General, concluded that the Üihang project had proved fruitless. After the project's completion, monks had scattered, even throwing away their identification tags, and the canal had collapsed and "become filled in with sand." 35

Finally, in 1539, Chosŏn officialdom turned on the architect of the last viable canalization project on the T'aean peninsula. A report from the Office of the Inspector-General (Sahŏnbu) denounced Yi Hyŏn, by now magistrate of Tamyang, as a "wicked and ill-mannered" man who conspired with eunuchs and royal relatives and "accepted numerous bribes" during his tenure as head of the Üihang canalization project. The Inspector-General report goes on to claim that Yi counted monks "who barely came out to work" on the corvée rosters. He even supposedly used project resources to reclaim mud flats into private fields. The Inspector-General recommended his removal from office, and the king assented.

It is possible that Yi Hyŏn was simply a convenient scapegoat for yet another failed canalization effort in the T'aean mud flats. The accusations seem far-fetched, especially considering that King Chungjong had only recently bestowed Yi with so many accolades. More likely, the collapse of the Uihang canal allowed numerous officials to express their displeasure at the use of despised groups such as monks and the elevation of upstarts such as Yi Hyŏn. Combined with the already long legacy of canalization failures in the T'aean region, continuous efforts became difficult to justify.

The Chosǒn government would never again attempt to canalize through the Anhŭng headland. Southern grain shipments, however, continued to maintain importance, necessitating attention to transportation infrastructure. According to a government report from 1640, a full 93 percent of grain taxes came from the three southern provinces of Chŏlla,

35 Chungjong sillok 33.9.27. 
Kyŏngsang, and Ch’ungch'ŏng, with Chŏlla alone comprising 48.5 percent of the total. ${ }^{36}$ After the sixteenth century, the government became more reliant on the use of merchant brokers and the encouragement of private shipbuilding. ${ }^{37}$ The government also regularly corvéed people to man government transport vessels, but the work was considered dangerous, and corvéed sailors had a propensity to flee. ${ }^{38}$

In the late seventeenth century, the Chosŏn government expanded transport infrastructure through an array of transport hubs and strategically placed granaries. In 1669, the famed statesman and scholar Song Siyŏl (1607-1689) proposed placing new granaries at the southern and northern ends of the T'aean peninsula. Accordingly, northbound ships could drop off their grain while avoiding the Anhŭng headland. The grain would then be transported a short distance northward by land to be picked up by southbound ships from Seoul. ${ }^{39}$ While less efficient then a continuous voyage, Song Siyŏl's solution allowed ships to reduce losses and placated the fears of corvéed sailors.

Thus, though attempts to canalize the Anhŭng headland ceased, grain shipments wedded the Chosŏn state to infrastructural projects in the T'aean region. During the reign of King Injo (r. 1623-1649), the Chosŏn government ordered military garrisons based in Ch'ungch'ŏng province to excavate a waterway through a narrow chokepoint at the southern extension of the T'aean peninsula. The successful excavation created a new island, known as Anmyŏn after its northernmost village, and allowed transport ships to sail through the calm waters of Ch'ŏnsu Bay before moving west toward the Anhŭng headland (Fig. 3). ${ }^{40}$ Even as late at 1826,

36 Choe Wan'gi, Chosŏn hugi sŏnunŏpsa yŏn'gu, 31; Injo Sillok 18.12.1.

37 Choe Wan'gi, Chosŏn hugi sŏnunŏpsa yŏn'gu, 22-23.

38 Choe Wan'gi, Chosŏn hugi sŏnunŏpsa yŏn'gu, 33-34.

39 Hyŏnjong sillok 10.2.3.

40 Yu Yŏngsaeng, “T'aean pando kulp'o unha ŭi yŏksa chiri chŏk koch'al [A historical-geographical examination of the Kulp'o canalizations in the T'aean peninsula]," Chirihakyŏn'gu 15 (1990.6), 54-55. 
royal inspectors investigating local conditions in the T'aean region would take the initiative to examine the old canal works and quiz locals about the feasibility of another canalization effort. ${ }^{41}$

41 Kim Myŏngsuk, “Amhaeng ŏsa Kim Chŏnghŭi ka pon 19 segi chŏnban'gi Ch'ungchŏngudo ŭi sahoesang [The social conditions of Chŭngchŏng Right Province in the early nineteenth century as seen by Secret Royal Inspector Kim Chŏunghŭi]," Han'guk sasang kwa munhwa 37 (March 2007): 178. 


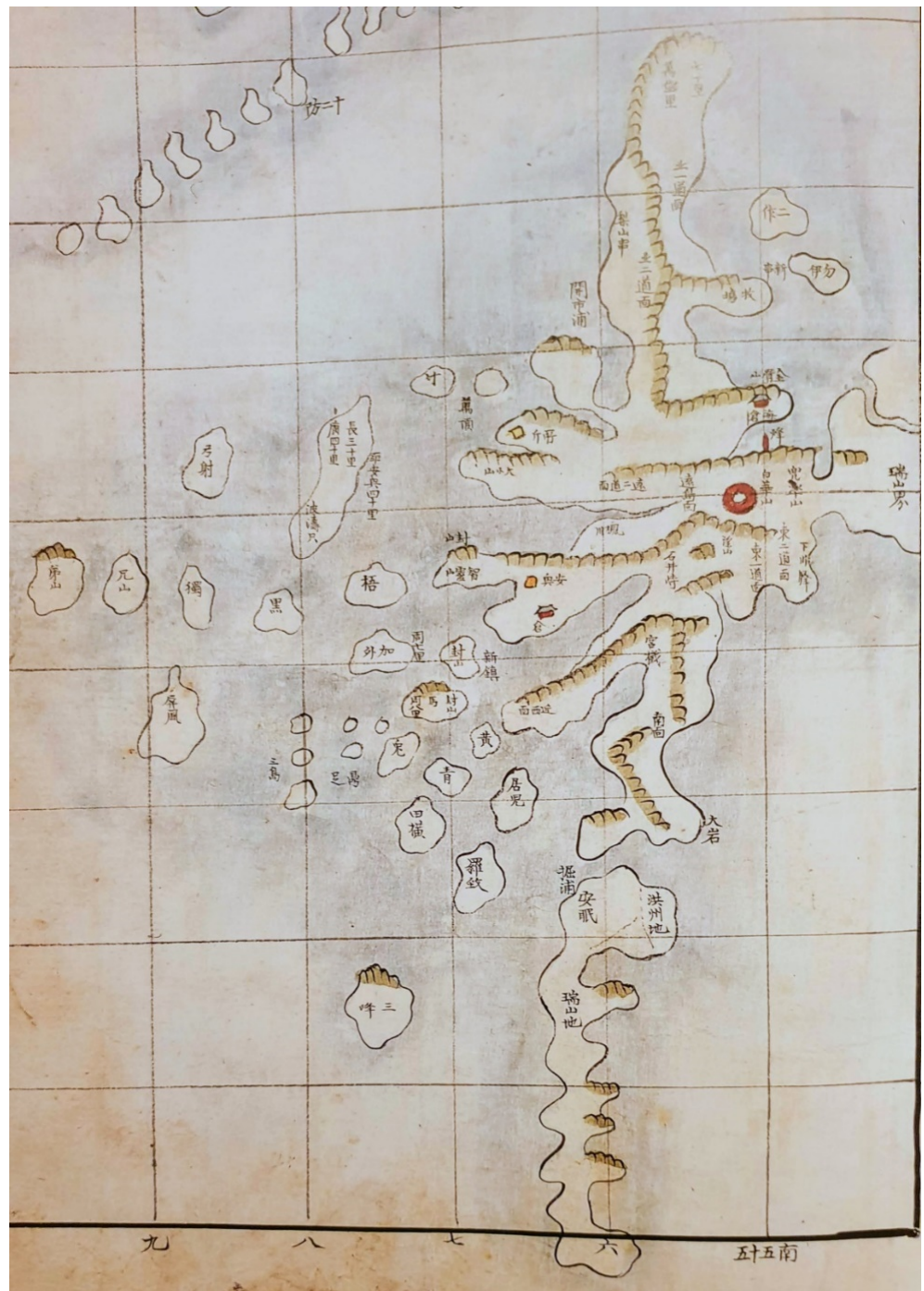

Source: Map of T'aean County in the Haedong Yöjido [Map of the East of Sea], vol. 1. (Seoul: National Library of Korea, 2005)

Fig. 3. The T'aean peninsula in the late eighteenth century. The red buildings mark the location of granaries. Anmyŏn is the island extending from the southern end of the T'aean peninsula. 


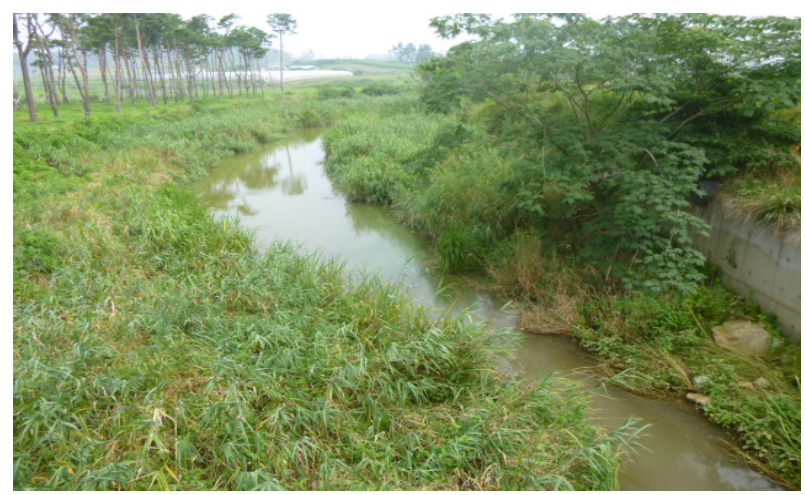

Source: Photo by author

Fig. 4. Contemporary remnants of the Kulp'o canalization site. The area long ago gave way to paddy fields and irrigation dikes.

\section{Conclusion: The Environmental Limits of the Infrastructural State}

What do the failure of the T'aean canals indicate about Chosŏn society? Chosŏn-era officials attributed the canal's failures to a lack of willpower and general malaise:

"Although Wang Kang was ultimately not able to excavate [the canal], how was he able to accomplish such a great task with the previous dynasty's lax order and weak corvée system? ... In China, they even excavate canals of over 500 li. This Kul'po project is crossing soil and marsh of but only $20 \mathrm{li}$. Because our country's people have a shallow psyche and have never undertaken great affairs, they take everything to be difficult. ${ }^{42}$

For Chosŏn officials in the early sixteenth century, the failure of the

42 Chungjong sillok 31.9.27. 
T'aean projects only seemed to solidify negative comparisons with the Middle Kingdom. The failures, moreover, fit into the moralistic Confucian worldview of Chosŏn officialdom, in which an educated, cultured, and ethical elite deemed itself responsible for the kingdom's security and prosperity.

From our contemporary vantage, the failure of the T'aean canalization efforts also point to the environmental limits of the infrastructural state in pre-industrial Korea. Historical sociologist Michael Mann defined infrastructural power as the logistical capacities through which the state penetrates the social life of a polity. The key techniques of infrastructural penetration, he argues, included bureaucratic coordination, the spread of literacy, standardization of coinage and measures, and the development of communication and transport infrastructure. ${ }^{43}$ While pre-industrial states on the Korean peninsula were able to coordinate impressive bureaucratic capacities for political and social reform, they proved unable to overcome environmental barriers such as those of the T'aean region.

The history of Korea's canalization failures thus demonstrates how environmental factors shape the institutional paths of states over the longue durée. Each of the T'aean canal projects built upon the lessons, failures, and infrastructure provided by its predecessors. Unable and unwilling to discontinue predetermined patterns and preexistent infrastructure, officials and workers spanning five centuries would wrestle with the environmental challenges of the T'aean peninsula and the Anhŭng headland. Finally, after 1537, Chosŏn officials gradually took a different route. Middlemen brokers and private shipping took on a larger role in the grain transport system during the latter half of the Chosorn dynasty. The government continued to invest in the infrastructure of the $\mathrm{T}$ 'aean area but in the form of granary construction and alternative waterways such as the Anmyŏn project. Rather than pressing the environmental limits of the T'aean mud flats, Chosŏn officials, merchants,

43 Michael Mann, "The Autonomous Power of the State: Its Origins, Mechanisms and Results,” European Journal of Sociology 25, no.2 (November 1984): 116-117. 
and sailors found other paths.

In 2008, new South Korean President Yi Myŏngbak (Lee Myung-bak) came to office vowing to construct a 540-kilometer-canal that would traverse the Republic of Korea from Seoul to Pusan, connecting the Yellow Sea to the Korea Strait. Coined the "Pan Korea Grand Waterway" (Hanbando Taeunha), the proposed project would have involved monumental feats of tunneling through Korea's south-central mountain ranges and the dramatic transformation of South Korea's rivers into a unified canal system. Critics lambasted the plan as a pending environmental catastrophe and economic boondoggle, and Lee was forced to drop the project. More than a century after the end of the Chosŏn dynasty, infrastructural dreams and environmental realities still intertwine, lingering over abandoned canals and paths not taken.

\section{Bibliography}

1. Beunen, R. and J.J Patterson, "Analysing institutional change in environmental governance: exploring the concept of "institutional work," Journal of Environmental Planning and Management 62, no.1 (November 2019), 12-29.

2. Choe Wan'gi, Chosŏn hugi sŏnunŏpsa yŏn'gu [A History of Transport Shipping in the Late Chosŏn Dynasty]. Seoul: Ilchogak, 1993.

3. Chŏng Inji., et al. Koryŏsa [Standard Koryŏ History]. Edited by Sahoe Kwahagwŏn (Korea: North), Kŏjŏn yŏn'gusil. Seoul: Sinsŏwŏn, 2001.

4. Chosŏn wangjo sillok [The Veritable Records of the Chosŏn Dynasty]. Kwach‘ŏn, South Korea: Kuksa p'yŏnch'an wiwŏnhoe, 2005. http://sillok.history.go.kr.

5. Chungjong sillok. See Chosŏn Wangjo Sillok, n.d.

6. Haboush, Jahyun Kim and Kenneth Robinson, eds., A Korean War Captive in Japan, 1597-1600: The Writings of Kang Hang. New 
York, NY: Columbia University Press, 2013.

7. Hyŏnjong sillok. See Chosŏn Wangjo Sillok, n.d.

8. Injo sillok. See Chŏson Wangjo Sillok, n.d.

9. Kanno Shuichi, “Chosŏn ch'ogi chinhyulgok unsong munje: Chosŏn wangjo ŭi kukka chŏk chaebunbae kinŭng e taean koch'al [The problem of famine-relief grain transportation in the early Chosǒn era: An examination of the national redistributive functions of the early Chosǒn dynasty]" Komunsŏyŏn'gu 22 (February 2003): 193-222.

10. Kim Hyŏnjun, “Anhŭngnyang ŭi kulp'o: miwansŏng ŭi unha kongsa [The excavation of the Anhŭng headland: canal construction in Miwansŏng]," Chayŏn kwa munmyŏng ǔi chohwa 49, no.8 (August 2001): 6-9.

11. Kim Myŏngsuk, “Amhaeng ŏsa Kim Chŏnghŭi ka pon 19 segi chŏnban'gi Ch'ungchŏngudo ŭi sahoesang [The social conditions of Chŭngchŏng Right Province in the early nineteenth century as seen by Secret Royal Inspector Kim Chŏunghŭi]," Han'guk sasang kwa munhwa 37 (March 2007): 155-184.

12. Kim Sŭngnam, “16 segi Chosŏn ŭi p'iyŏk sŭng ŭi chŭngga wa sŭngdo chojik ŭi chaegŏn [The rise in labor-avoidant monks and monastic reorganization in sixteenth-century Chosŏn]. Chosŏn sidaesa hakpo 66 (September 2013): 53-88.

13. Kim Ǔiwŏn “Anhŭng yang kulp'o kaech'ak kwa kibŏp yon'gu [A study of the two canalization excavations on the Anhŭng headland]" Kukt'o kyehoek 16, no.2 (November 1981): 51-60.

14. Ko Tonghwan. Chosŏn hugi Sŏul sanŏp paltalsa yŏn'gu [The Development of Commerce in Late Chosŏn Seoul]. Seoul: Chisik sanŏpsa, 2002.

15. Koryŏsa [Standard Koryŏ History]. Kwach'ŏn, South Korea: Kuksa p'yŏnch'an wiwŏnhoe, 2015. http://db.history.go.kr/KOREA/

16. Koryŏsa chŏryo [Essentials of Koryŏ History]. Kwach’ŏn, South Korea: Kuksa p'yŏnch'an wiwŏnhoe, 2015. http://db.history.go.kr/KOREA/

17. Kwak Hoje, 'Koryŏ-Chosŏn sidae t'aean pando choun ǔi silt'ae wa 
unha kulchak [Canal excavation and the context of transport in the T'aean peninsula during the Koryŏ and Chosŏn eras]" Chibangsa wa chibang munhwa 12, no.1 (May 2009): 301-325.

18. Lee, John S., "The Rise of the Brokered State: Situating Administrative Expansion in Chosŏn Korea," Seoul Journal of Korean Studies 32, no.1 (June 2019): 81-108.

19. Mann, Michael, "The autonomous power of the state: its origins, mechanisms and results," European Journal of Sociology 25, no.2 (November 1984): 185-213.

20. Mun Kyŏngho, “Anhŭngnyang kwa kulp'o unha yujŏk kwallyŏn chimyŏng kŏmt'o [An examination of the geographical nomenclature concerning the Anhŭng headland and Kulp'o canal]," Tosŏ munhwa 43 (June 2014): 7-38.

21. Munck af Rosenschöld, Johan, Japp G. Rozema, and Laura Alex Frye-Levine, "Institutional inertia and climate change: a review of the new institutionalist literature," Wiley Interdisciplinary Reviews 5 (May 2014): 639-648.

22. Needham, Joseph, Wang Ling and Lu Gwei-djen. Science and Civilisation in China, vol. 4, Physics and Physical Technology, Part III: Civil Engineering and Nautics. Cambridge: Cambridge University Press, 1971.

23. Sejo sillok. See Chŏson Wangjo Sillok, n.d.

24. Sin Sukchu "Ch'a t'aean tonghŏn'un," Pohanchae chip 9 [1487], reprinted in Han'guk yŏktae munjip DB, vol. 59. P'aju, South Korea: Han'guk yŏktae munjip DB.

25. T'aejo sillok. See Chǒson Wangjo Sillok, n.d.

26. T'aejong sillok. See Chŏson Wangjo Sillok, n.d.

27. Yi Chongyŏng, Chosŏn chŏn'gi sahoe kyŏngjesa yon'gu [A Study of the Social and Economic History of the Early Chosŏn Era]. Seoul: Yonsei kukhak ch'ongsǒ, 2003.

28. “_Anhŭngnyang taech'aek ŭrosouŭi T'aean chogŏ mit anminch'ang munje [The T'aean waterway through the Anhŭng headland and the problem of the granary system]" Tongbang hakchi 7 
(December 1963): 99-133.

29. Yu Yŏngsaeng, “T'aean pando kulp'o unha ŭi yŏksa chiri chŏk koch'al [A historical-geographical examination of the Kulp'o canalizations in the T'aean peninsula]," Chirihak yŏn'gu 15 (June 1990): 47-60. 


\section{The Waterlogged Limits of the Infrastructural State: The Failure of the T'aean Canalization Projects in Pre-Industrial Korea, 1134-1537}

John S. Lee

One of the chronic problems of pre-industrial Korean history has been the difficulty of material integration between core regions of the Korean peninsula. This article analyzes five major canalization attempts made by Koryŏ and Chosŏn states in the T'aean region to address the problem of infrastructural integration. Located along a critical shipping route between the southern grain basket and the capital region, the T'aean coastline had been infamous for centuries for its treacherous tides and proclivity for hastening shipwrecks. Consequently, from 1134 to 1537, Koryŏ and Chosŏn officials attempted canalization projects that, if successful, would have allowed grain ships to bypass the most troublesome zones. However, the canalization efforts all ended in failure. Utilizing Chosŏn-era institutional records, I argue that the canalization failures: 1) exposed a pre-industrial state's logistical and technological limits, notably, the difficulty of coastal canalization efforts in areas of high tidal variation and granite bedrock, and 2) prompted shifts in the infrastructural priorities of the Chosŏn state.

Keywords: Koryŏ, Chosŏn, T’aean, Anhŭng, infrastructural state, canals, maritime transport 
<국문초록>

\section{하부구조적 권력의 물에 잠긴 한계: 전근대 태안반도 운하굴착 사업의 고찰, 1134-1537}

John S. Lee (Durham University)

전근대 한국 국가의 문제점 중 하나는 한반도의 물질적 통합의 어려움이 었다. 이 글은 고려 조선조가 태안반도에서 여러 차례 시도했던 운하 굴착 사업을 분석한다. 삼남지방과 수도 지역 사이의 중요한 항로를 걸친 태안 반도의 해안선은 지형적으로 암초와 천퇴가 많았고 해류가 매우 빨랐기 때 문에 선원들 사이에서 악명이 높았다. 이에 따라 1134년부터 1537년까지 국 가와 위정자들은 해난사고를 피하려고 대규모의 운하 공사를 수행하였다. 그러나 모두 실패로 끝났다. 이 글은 태안반도 운하 사업의 실패가 전근대 국가의 기술- 인프라의 한계를 드러냈다고 주장한다. 그리고 조선조는 태 안반도의 부적당한 해안선을 대규모 공사로써 극복할 수 없어 조선 중기 이후 운송 기반시설대해 다른 전략을 추구했다.

주제어: 고려, 조선, 태안, 안흥, 운하, 해안 수송, 하부구조적 권력 